\title{
The academic anxiety of students in pandemic era
}

\author{
Ulin Nihayah ${ }^{1}$, Ahmad Shofwan Ats-Tsauri Sadnawi ${ }^{2 *}$, Nuha \\ Naillaturrafidah $^{3}$ \\ 1,2,3 Universitas Islam Negeri Walisongo, Semarang, Indonesia \\ Email: ahmadshofan652@gmail.com
}

\begin{abstract}
Purpose - The purpose of this study was to describe the problems of academic anxiety that occur in college students as a result of the COVID pandemic that occurs and alternative solutions to overcome them in the perspective of counseling guidance.

Method - The research method used was descriptive quantitative, where the author conducts a survey to students who experience academic anxiety during the pandemic. The sample of the study consisted of 28 students from 9 universities

Result - The results of the research conducted are that the psychological anxiety disorders due to online lectures related to the influence of online lectures on student sleep patterns as much as $32.1 \%, 17.9 \%$ have difficulty sleeping, and $11.1 \%$ wake up sluggish. In addition, there are anxiety disorders due to online lectures that have a physical impact on the condition marked by $42.9 \%$ feeling lethargic and unmotivated, $14.3 \%$ achy, $28.6 \%$ eye strain, $14.8 \%$, so it has an impact on mastery of the material with the result that $82.1 \%$ can absurb master the material, and the rest did not master the material.

Implications - This study can be used to improve the problems of academic anxiety that occur in college students as a result of the COVID pandemic.

Originality - This research is the study analysis student academic-anxiety in dealing with online lectures by using the analysis of counseling guidance.
\end{abstract}

Keywords: Anxiety, college student, guidance counseling.

For citation: Nihayah, U., Sadnawi, ASA., Naillaturrafidah, N. (2021). The academic anxiety of students in pandemic era. Journal of Advanced Guidance and Counseling. 2(1). 39-55. https://doi.org/10.21580/jagc.2021.2.1.6986.

*Corresponding author: Ahmad Shofwan Ats-Tsauri Sadnawi (ahmadshofan652@gmail.com), Universitas Islam Negeri Walisongo SemarangJl. Walisongo No.3-5, Tambakaji, Kec. Ngaliyan, Kota Semarang, Jawa Tengah 50185.

Journal of Advanced Guidance and Counseling - Vol. 2 No. 1 (2021) 
Ulin Nihayah Ahmad Shofwan Ats-Tsauri Sadnawi, Nuha Naillaturrafidah

JAGC $\mid 40$

\begin{abstract}
Abstrak
Tujuan - Tujuan penelitian ini untuk mendeskripsikan permasalahan academic anxiety yang terjadi pada mahasiswa akibat pandemi COVID yang terjadi dan alternatif solusi untuk mengatasinya dalam perspektif bimbingan konseling.
\end{abstract}

\begin{abstract}
Metode - Metode penelitian yang digunakan adalah deskriptif kuantitatif, dimana penulis melakukan survey kepada mahasiswa yang mengalami academic anxiety selama masa pandemi. Sampel penelitian terdiri dari 28 mahasiswa dari 9 universitas.

Hasil - Hasil penelitian menunjukkan bahwa gangguan kecemasan psikologis akibat kuliah online terkait pengaruh kuliah online terhadap pola tidur mahasiswa sebanyak $32,1 \%$, sulit tidur $17,9 \%$, dan bangun lamban $11,1 \%$. Selain itu terdapat gangguan kecemasan akibat kuliah online yang berdampak pada kondisi fisik yang ditandai dengan $42,9 \%$ merasa lesu dan tidak bersemangat, $14,3 \%$ pegal, $28,6 \%$ mata tegang, $14,8 \%$ sehingga berdampak pada penguasaan materi. dengan hasil $82,1 \%$ dapat menguasai materi, dan sisanya tidak menguasai materi.

Implikasi - Penelitian ini dapat digunakan untuk memperbaiki masalah kecemasan akademik yang terjadi pada mahasiswa akibat pandemi COVID.

Originalitas - Penelitian ini merupakan penelitian analisis kecemasan akademik mahasiswa dalam menghadapi perkuliahan online dengan menggunakan analisis bimbingan konseling.
\end{abstract}

Kata kunci: Kecemasan akademik, mahasiswa, bimbingan konseling.

\title{
Introduction
}

The COVID-19 pandemic has attacked almost all parts of the world to Indonesia, since the Indonesian president announced the first case of COVID-19 on March 2, 2020, Indonesia has directly become part of the country affected by this virus. Various policies were also adopted to prevent the spread of COVID-19, including the education-sector (https://sevima.com/5-kebijakan-pendidikanmasa-darurat-corona/). One of the policies carried out by the government is the implementation carried out by the Indonesian Minister of Education, on June 15, 2020 where it was decided that the higher education process would be conducted online.

The pratice of online lectures has a tremendous impact on the learning process that is not commonly used in Indonesia. Several things need to be deliberately prepared, starting from the process of delivering material, controlling lecturer 
attendance to the assessment stage which is things that often get attention in the whole process. It is inevitable that new habits towards online lectures will have a psychological impact, including student-anxiety in taking online lectures.

Some of the discussions related to academic anxiety have been discussed previously. Among the research related to anxiety disorders due to online learning JAGC | 41 is research conducted by Amar (Saputra, 2010) where the research conducted related to the symptoms of panic and worries that occurred due to the COVID pandemic was carried out in Aceh-Yogyakarta. The results of the conductedresearch showed that there was resilience in the face of COVID-19, where the ability of students to deal with situations that occurred calmly and determined rational steps in various actions and had a positive outlook in facing the challenges being faced. Also, the research conducted by Leo $\mathrm{Ng}(\mathrm{Ng}, 2021)$ was obtained information about the existence of increasing negative feelings such as anxiety and stress that could reduce learning motivation, besides that students tended to say that face-to-face learning would provide social support because it could facilitate feedback from friends and tutors at school. In the other hand, Valiante and Pajares mention (G \& Pajares, 1999) states that: Academic-anxiety is a feeling of tension and fear of something that will happen, these feelings interfere the performance of doing various tasks and activities in academic situations.

Based on the phenomena mentioned above, it is explained that academicanxiety is considered a profound problem and demands a solution. An immediate solution is also a way to solve this problem. The provision of appropriate guidance and counseling services for students who experience academic-anxiety due to the online lectures must be done through a counseling approach and in-depth analysis in providing assistance to students in higher education.

Counseling guidance in higher education is a form of independence in overcoming problems, it is carried out by students accompany with counselors. This is inseparable from the resolution of academic, individual, social and religious problems experienced by students, although in a broader scope than students' issue. Mentioned by Alifia (Putri, 2018) that in early adulthood, students tend to have problems in living their life, both in terms of individual, social, physical, cultural and other aspects. Therefore, it is absolutely necessary for the role and assistance 
of a counselor in guiding early adults in carrying out their developmental tasks. By doing so, early adults can complete their developmental tasks as optimally as possible in order to get a happy life in the future. For that reason, the author tries to reveal the students' problems, one of which is related to student academicanxiety in dealing with online lectures by using the analysis of counseling guidance.

\section{Research Method}

The used-type of research was descriptive quantitative. Quantitative descriptive is a type of research that is used to analyze data by describing the data that has been collected as it is (Sugiyono, 2015). The sample of the study consisted of 28 students from 9 universities in Indonesia, namely Universitas Islam Negeri Sunan Kalijaga, Universitas Islam Negeri Walisongo Semarang, UNSOED Purwokerto, Siliwangi University, Institut Agama Islam Negeri Pekalongan, UNNES, Universitas Muhammadiyah Surakarta, and Institut Agama Islam Negeri Gajah Putih Aceh. The obtained-Respondents were the students from semester 3, 5 and 7 with the technique of random sampling through a distributed questionnaire survey. In addition, the students as a subject of this research were the students who carry out online lectures during the COVID-19 pandemic. The object of this research was the academic-anxiety of students in conducting online lectures during the pandemic and the influence experienced on the acceptance of learning materials during the COVID-19 pandemic.

\section{Results and Discussion}

\section{The Concept of Anxiety}

A person sometimes feels anxious when facing something that is uncertain and cannot be predicted in his activities. Normal anxiety will usually mitigate on its own when the anxiety triggering factor disappears. For example, someone who feels anxious when facing an exam will come back to calm after the exam is over. However, in contrast to abnormal anxiety, people who experience excessive anxiety will usually continue to feel anxious for no apparent reason. The emergence of excessive anxiety is often caused by anxiety disorders. People who experience excessive anxiety often feel excessive fear and apprehensive 
continuously. Over time, this anxiety disorder can get worse and interfere with a person's mental health.

The term worry is commonly known in English as "Anxiety". According to Steven Schwartz anxiety comes from another word "anxius", which means constriction or strangulation. Anxiety is similar to fear but not specifically, whereas fear or dread is usually a response to some immediate threat, whereas anxiety is characterized by worry about unforeseen dangers that lie in the future. Anxiety is a negative emotional state characterized by premonition and somatic tension, such as a racing heart, sweating, and difficulty breathing.

Jeffrey S. Nevid, et al suggested that anxiety is an emotional state that is characterized by physiological information, an uncomfortable feeling of tension, and an understanding feeling that something bad will happen. (S et al., 2005) Meanwhile, Gail W. Stuart states that anxiety is a vague and diffuse worry associated with feelings of uncertainty and helplessness. (Annisa, 2016) Anxiety can be referred to as a symptom in which an emotional state with uncomfortable feelings in a person, and is a vague experience accompanied by feelings of helplessness and uncertainty caused by something that is not clear.

The excessive anxiety conditions, if the victims do not get a treatment, those people with anxiety disorders who feel excessive anxiety can have difficulty in carrying out daily activities, it decreases work performance or learning achievement at school, and it also has difficulty undergoing social interactions with other people. Anxiety that arises from a person has a range of responses that describe the quality or level of anxiety he experiences. The range of anxiety responses can be described starting from the individual's response to anticipating mild, moderate, severe anxiety or even panic. Range of adaptive responses to anticipation of anxiety, mild to moderate anxiety. While the range of maladaptive responses is found in severe anxiety and panic.

The level of anxiety has different characteristics. At a mild level of anxiety there is an increase in alertness, sharpening of senses, and expansion of the field of view. At a moderate level of anxiety, cognitive has focused on the stressor, there is a narrowing of the perceptual field but is still able to do things and make decisions 
with the help of others. In severe anxiety, attention is completely focused on even more specific things with a very narrow perceptual field so unable to think for anything else. Likewise, at very severe levels of anxiety, individuals lose control, control, rationality and individual perception deviations, unable to carry out any activities, even with many directions from others. Individuals only focus on things that are worried about and ignore everything, including to meet daily needs such as eating, bathing and so on (Ratnawati, 2018). Anxiety is highly influential on a person's mental health. When anxiety charges a person or when there is no condition that is worth worrying about but the person feels anxiety, then his mentality and psychology are disturbed.

The existence of conflicts that occur in humans often causes an imbalance in spiritual life which is mentioned in mental health as spiritual complexity. By doing so, this spiritual complexity is referred to as a functional complexity that causes a person's mental disorder. (Hawari, 1995). Muhammad Mahmud explained that there are 2 patterns in defining mental health. The first is a negative pattern (salabiy), where a mentally healthy person is a condition of avoiding a person from all neuroses (al-amradh al shabiyah) and psychological (al amradh al dzibaniyah). The second is a positive pattern condition (ijabiy) where mental health is an individual's ability to adjust to himself and his environment. (Mahmud, 1984)

During a pandemic like today, Indonesia, which is also a victim, is experiencing problems, one of which is in the field of education. The pandemic that requires face-to-face activities to be reduced in order to break the chain of the spread of the COVID-19 virus which can have an impact on educational learning activities in Indonesia, teaching and learning activities that should be carried out face-to-face between teachers and students have switched to online activities, which are all online. This also applies at the university level. This problem is not only felt by students but also lecturers, although it is more dominant to students. Such as giving assignments by lecturers, because in order to support lectures that can only be done using the video conference method or even just audio voice-notes, it becomes a scourge for students, because students feel that assignments are more piled up, it is coupled with special needs for the sake of running lectures on the network is the existence of quotas or internet data and also a strong signal to be 
connected so that they can receive material from lecturers. Those are all part of the factors that cause academic-anxiety of students. Academic- anxiety affects the results of the student achievement index and more importantly affects the enthusiasm in the lecture process.

\section{Academic-Anxiety Survey}

A year of the conducted-online learning has an effect on new habits. Symptoms of insomnia experienced as a result of online learning can cause dizziness to prolonged stress as a result of anxiety symptoms. Not only that, prolonged and excessive anxiety will have an impact on individual mental health. It is normal for a person to experience anxiety when facing something stressful, especially when online learning is being carried out. Nonetheless, if anxiety occurs without cause and there is excessive worry, then it is included in the symptoms of anxiety disorders and has an impact on mental health.

Table 1. The indicators of instrument

\begin{tabular}{clc}
\hline Variable & \multicolumn{1}{c}{ Indicator } & $\begin{array}{c}\text { Number of } \\
\text { respondents (\%) }\end{array}$ \\
\hline & $\begin{array}{l}\text { Insomnia (difficulty } \\
\text { falling asleep) } \\
\text { Waking up in the middle }\end{array}$ & $5(17,9 \%)$ \\
Psychological & of the night & $3(7,1 \%)$ \\
Anxiety & Not sleeping well & \\
& Wake up listlessly & $8(32,1 \%)$ \\
& Nightmare & $3(10,7 \%)$ \\
& Ordinary & $1(3,6 \%)$ \\
& & $8(28,6 \%)$ \\
& Lethargic and & $12(42,9 \%)$ \\
& unmotivated & $8(28,6 \%)$ \\
& Eyes strain & $4(14,3 \%)$ \\
Body aches & $4(14,3 \%)$ \\
& Others & 0 \\
& Muscle ache &
\end{tabular}


Ulin Nihayah Ahmad Shofwan Ats-Tsauri Sadnawi, Nuha Naillaturrafidah

\begin{tabular}{|c|c|c|c|}
\hline & Variable & Indicator & $\begin{array}{c}\text { Number of } \\
\text { respondents (\%) }\end{array}$ \\
\hline & \multirow{3}{*}{$\begin{array}{c}\text { Retention of } \\
\text { subject material }\end{array}$} & No & $23(82,1 \%)$ \\
\hline & & Perhaps & $4(14,3 \%)$ \\
\hline JAGC | 46 & & Yes & $1(3,6 \%)$ \\
\hline
\end{tabular}

An individual who experiences anxiety is caused by the high production of the hormone thyroxine in the human brain. Someone who experiences negative emotional processes will stimulate the hypothalamus to produce high levels of the hormone thyroxine. This causes individuals to get tired easily, easily anxious, easily tensed, easily afraid, and have difficulty sleeping, so that the individual's condition becomes less than optimal. ( $R, 2014)$

The results of a descriptive (survey) with a sampling technique: probability sampling (simple random sampling) where samples were taken from students at 9 universities. The measurement of the research used a questionnaire in the form of 14 questions. The obtained data is that online lecture anxiety is related to the effect of online lectures on students' sleep patterns as much as $32.1 \%$ experience poor sleep, $17.9 \%$ have difficulty sleeping, $11.1 \%$ wake up listlessly and $28.6 \%$ are normal.

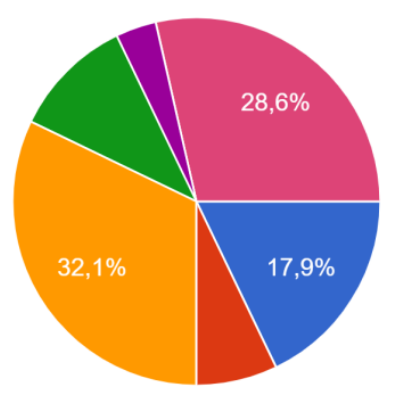

Figure 1. Diagram of the effect of online lectures on sleep patterns 
On the other hand, according to Kandouw in Hawari (2007) mention that the anxiety that has characteristics as below:

a. Physical Symptom is stiff and tense or ache muscles, the five senses or eye muscles that regulate the eye lens work overly so that the eyes become tired, the buzzing ears, the increased cardiovascular system such as heart pounding and increased blood pressure, disruption in the digestive system such as abnormal pain, nausea or diarrhea, distruption to the urinary system such as often urinating, disorders of the women' reproduction in the form of menstrual disorders or erectile dysfunction toward men. The other symptoms are that the skin feels hot, cold or itchy.

b. Psychological Symptom is increasingly anticipating everything, irritable, depressed, restless, difficult to relax, easily tired, easily surprised, scared, sleep disorders. If it is implemented, anxiety that occurred due to the existence of online lectures is obtained as follows: $42.9 \%$ feeling lethargy and not excited, $14.3 \%$ body aches, $28.6 \%$ tense eyes, $14.8 \%$ others.

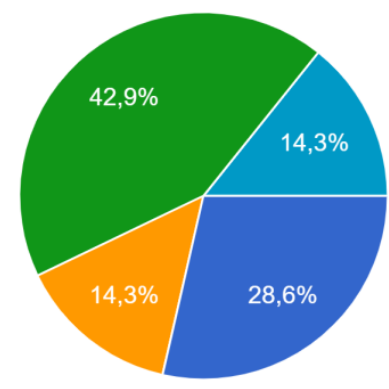

\section{Figure 2. The diagram results toward the effect of online lectures to body condition}

Based on the result in facing anxiety toward university-students in campus academic environment, anxiety becomes a large spectre so that anxiety in students is not uncommon to make problems directly related to degradation in academic assessment. By doing so, the material retention from the conducted survey results related to the level of students' understanding of the material during online lecture 
in the network is $82.1 \%$ can not master the material, and the rest masters the material.

JAGC | 48

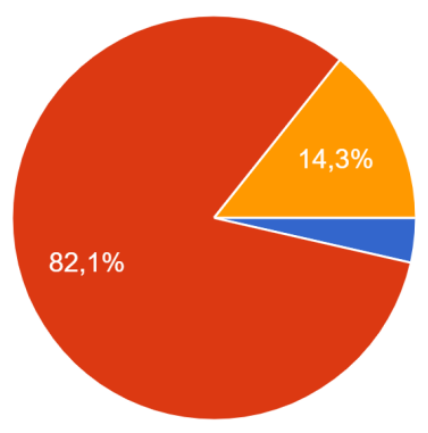

Figure 3. The diagram results of material mastery in online lecture

\section{The Analysis of Alternative Counseling Guidance Solutions}

Anxiety is able to attack at any time in individuals who have an anxiety disorder diagnosis, however anxiety can be controlled, the control of anxiety is the efforts in overcoming disturbing anxiety (neurotic anxiety), this control is a part of selfcontrol, it is a process where a person changes his behivour with certain way, directing himself and able to realize about the anxiety he experienced and able to control it without the help of others. If excessive anxiety occurs, a person will do an alternative such as consulting through the counsellor who is expert in his field.

The terms come from English words which are "Guidance" and "counseling". Guidance comes from the root of word: "guide" which is subtly meaningful: to direct, to pilot, to manage, to descript, to motivate, helping to create, to giving, to commit, the giver of consideration, and to behave as democratic performance. By doing so, if it is assembled in a sentence that the concept of guidance is a democratic effort and truly to provide assistance by delivering directives, guidelines, encouragement and consideration in order to make someone who gets a help can manage and reliaze what is his hope (Tirmidzi, 2018). 
In Arabic literature, the word "counceling" means alirsyad or al-istisyarah, while the word "guidance" means at-taujih. Therefore, guidance and counseling are said to be at-taujih wa al-istisyaroh or at-taujih wa al-irsyad. While etymologically, the word "irsyad" means al-huda, ad-dalalah, in Indonesia Language, it means a direction, and the word "istisyaroh" means talaba minh annasihah or talaba minh ut-masyural, in Indonesia Language, it means asking for advice or consultation (Fauziah et al., 2017).

Counseling itself is a process to give a help with interpreting the facts that are exist, they are the data about individual who is guided about his environment, especially related to the created plans. So it is good that the form of consultation is in the form of an alternative choice in overcoming anxiety but it is inseparable from the controls carried out by the counsellor as a companion.

Academic-Anxiety which occurs to university-students influences psychologically and physically with the result that it becomes an anxiety disorder. The effects of anxiety that is occurred also influence the acceptance of the subject material in the online lecture that tend to be not done well. It can even have an impact on the degradation of academic score. The implementation of guidance and counseling with the limited space and time can be done with individual counceling. According to Brammer (1979), the process of counseling is an event that has been going on and gives a meaning to a person who do counseling, namely counsellor or clients.

Every stage of process, individual counselling needs a certain skill. However, the skils are not the main one if the relationship of individual counselling does not reach a situation such as understanding each other and getting to know the shared goals because it is expected that the individual counselling process is not felt by counselling participant (counsellor and client) as a drab thing. By dong so, their involvement in the counselling process from the beginning to the end is felt extremely powerful and useful.

The individual counselling phase in overcoming academic-anxiety in online lectures is as follows: 


\section{a. The Initial Stage of Counselling}

This stage occurs when the client meets a counsellor until the counselling process runs to the counsellor and client find the definition of client's problem JAGC | 50 based on an issue, compassion, atau client's problem. With the limited space and time toward the implementation of the initial stage of counselling, then the client can use the individual counselling forms through internet media without having to meet and face-to-face directly with the counsellor in the pandemic era.

In this case, the relationship of counselling means that if the client is involved in discussing with a counsellor. This relationship is called a working relationship, it is a relationship which is functioning, meaningful and useful. The success of the individual counselling process is extremely determined by success at this initial stage.

In the other hand, in this stage, there are proximity between students and counsellors so that there is a good braid involving cooperation that can raise the issue of concern for clients. It is often in this stage that a client can not explain his problem clearly, although what is felt to be a symptom conveyed to the counsellor. Because of that, it is important for a counsellor to clarify a problem which is experienced by a client.

In this initial stage, there is a contract agreement that occurs between clients and counsellors. The opportunity in question is the client's desire to change the situation with the input from the counsellor. So that problem solving is not centered on the counselor alone, but is supported by the responsibility of the client and an invitation to work with the counselor to carry out the counseling process together.

\section{b. The Mid-Stage (Work Stage)}

At this stage, counselors try to help clients gain new perspectives, new alternatives that are different from previous problems, including decision making in overcoming academic anxiety due to online lectures. If the client feels excited to engage and communicate with the counselor further. Clients will see the problem 
from another perspective and are objective and it is even possible to find various alternatives.

Meanwhile, the form of academic anxiety that occurs can be done by doing relaxation by eliminating academic anxiety in attending online lectures. One therapy to overcome anxiety is relaxation, relaxation is a behavioral therapy JAGC | 51 technique that can reduce tension and anxiety. Relaxation also has various methods, one form of relaxation that can be adopted to control anxiety is breathing relaxation. This form of relaxation is called breathing relaxation which can be done in situations where complicated relaxation is not possible. For example, when you are going to make a presentation in front of a crowd, someone experiences tension and anxiety, before making the presentation someone can relax so that anxiety can be reduced. This relaxation is seen as an easy and inexpensive way to turn stress and anxiety into a passion for life, and can control emotions and delay anger before deciding on a wiser course of action.

This relaxation method is as follows:

1) Sit up straight relaxed and not tense.

2) Take a deep breath and then exhale slowly, preferably with your eyes closed. Repeat three, four times, or more.

3) Feel the warm and cold air flowing in and out of your nose.

4) After a few times doing the things above, a person will be able to control his breathing.

5) Recognize breathing patterns when anxious, stressed, irritated, or tense. The more skillfully you can feel the flow of air through your airways, the more adept you will be at controlling your breathing, you can change your emotional mood to be calmer and more relaxed, anytime.

By adjusting the breathing pattern, this will find an opening to get out of even the most stressful situations. The living space is getting wider and the spirit of life is increasing. Logically, when anxious, panicked, stressed, tense, or emotionally unstable, breathing becomes bad and short, also short of breath. Oxygen intake into the lungs is not optimal so that it affects oxygen levels in the blood. As a result, 
Ulin Nihayah Ahmad Shofwan Ats-Tsauri Sadnawi, Nuha Naillaturrafidah

the body's cells, including brain cells, are deprived of oxygen. Lack of oxygen in brain cells will disrupt and interfere with bodily activities and emotions. By taking a deep breath, the oxygen supply increases to meet the needs of the brain cells and the body (Hayat, 2014) .

Meanwhile, to prevent the emergence of anxiety disorders can be done in two steps:

1) Internal

This raises positive thoughts, controls emotions well, and gets rid of all excessive worries about a condition or future.

Allah says in the Qur'an Surah At-Taghabun Verses 11-13:

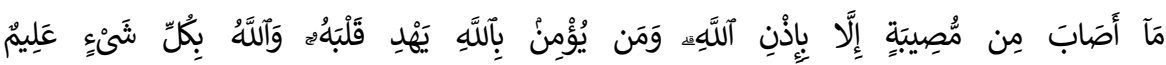

No calamity befalls a person except by Allah's permission; And whoever believes in Allah, He will guide his heart. And Allah is knowing of all things.

\section{2) Eksternal}

Associating with people who bring positive energy, good personality and a healthy mentality will make the individual more calm and relaxed so that anxiety rarely appears.

In a hadith Rasulullah shallallaahu 'alaihi wa sallam explains the role and impact of making friends with someone who has a good personality, in his words:

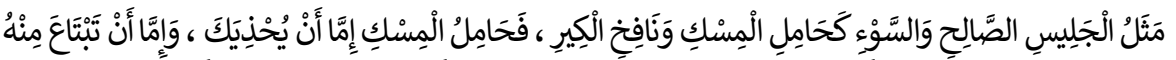

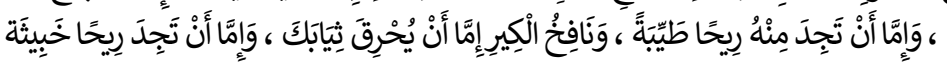

"A good friend and a bad friend are like a perfume seller and a blacksmith. The perfume seller may give you perfume, or you can buy perfume from him, and even if you don't, you still get a good smell from him. As for the blacksmith, it could be (sparks) on your clothes, and even if you don't, you still get the unpleasant smell of smoke." (HR. Bukhari 5534 and Muslim 2628)

In addition, alternative forms of solutions to overcome academic anxiety that occur due to online lectures can be done with the therapy of the verses of the 
Qur'an, as was done in Sholeh's research (2016). The form of implementation of this verse therapy in relaxation can be done by reading short letters that are commonly used daily, on a regular basis. This is done with the aim of reducing anxiety that occurs in assessments or when presenting in online lectures. In addition, students can perform the form of prayer before and after lectures independently even without being guided by the lecturer. The attitude of surrender in worship by drawing closer to God can be done as a form of relaxation in academic form when online learning is carried out. Spiritual strength in humans, with sincere worship, continuous obedience, tawaddu' wara', surrender to destiny, patience over calamities, able to bring peace and complete mental health.

\section{c. The Third Stage}

This third stage is the final stage of counseling. The forms of activities carried out are marked by several things, namely:

1) Decreased client anxiety. This is known after the counselor asks the state of his anxiety.

2) There is a change in the client's behavior towards a more positive, healthy, and dynamic direction.

3) There is a future life plan with a clear program.

There is a change in positive attitude, namely starting to be able to self-correct and eliminate attitudes that like to blame the outside world, such as parents, lecturers, friends, unfavorable circumstances and so on. So the client is thinking realistically and confidently. So that the form of the problem from the client is resolved properly.

\section{Conclusion}

Academic-anxiety in the implementation of online lectures is extremely common. This is a form of individual response in responding to the implementation of online learning that occurs. The results of the research conducted are that there is a relationship between academic anxiety that occurs in students and has an impact on the degradation of the value of students who cannot absorb lecture material as much as $82.1 \%$. In addition, the psychological impact of students due 
Ulin Nihayah Ahmad Shofwan Ats-Tsauri Sadnawi, Nuha Naillaturrafidah

to academic anxiety in online lectures resulted in problems related to student sleep patterns as much as $32.1 \%, 17.9 \%$ had difficulty sleeping, and $11.1 \%$ woke up listlessly. While the physical impact of academic anxiety due to online lectures that JAGC | 54 occurred was $42.9 \%$ with conditions feeling lethargic and not enthusiastic, $14.3 \%$ achy, $28.6 \%$ eye strain, $14.8 \%$. The alternative form of solution in overcoming academic anxiety is individual counseling where the counselor and client carry out the form of counseling implementation through 3 stages, namely: the initial stage with the approach process carried out and the formulation of the problems that occur. Furthermore, there is an intermediate stage where there is a form of implementation of the work stage for the implementation of counseling through relaxation and the final stage as a result of the positive effects of the implementation of the counseling carried out.

\section{References}

Annisa, D. F., \& Ifdil, I. (2016). Konsep kecemasan (anxiety) pada lanjut usia (lansia). Konselor, 5(2), 93-99. https://doi.org/10.24036/02016526480-0-00.

Brammer. (1979). Layanan konseling. Usaha Nasional.

Fauziah, L, S., \& Salminawati. (2017). Implementasi konseling islami dalam membina kepribadian siswa di SMK Negeri 1 Tanjung Tiram Kabupaten Batubara. Jurnal Edu Riligia, 1(2). http://dx.doi.org/10.47006/er.v1i2.895.

G, V., \& Pajares. (1999). He inviting/disinviting index: Instrument validation and relation to motiation and achievement. Journal of Invitational Theory and Practice, 6, 28-47.

Hawari, D. (1995). Ilmu kedoktran jiwa dan kseharan jiwa. Dana Bhakti Prima Jasa.

Hayat, A. (2014). Kecemasan dan metode pengendaliannya. Jurnal Hayat, 12(60). https://dx.doi.org/10.18592/khazanah.v12i1.301.

https://www.cnnindonesia.com/nasional/20200615182023-20-

513564/akademik-kampus-agustus-nadiem-larang-kuliah-tatapmuka. (n.d.).

https://sevima.com/5-kebijakan-pendidikan-masa-darurat-corona/ 
Mahmud, M. (1984). 'ilm al nafs al ma'ashir fi dhaw 'I al islam. Dar al Syaryq.

$\mathrm{Ng}$, L. (2021). Elearning in physical therapy: Lessons learned from transitioning a professional education program to full elearning during the COVID-19 pandemic. Physical Therapy \& Rehabilitation Journal. https://doi.org/10.1093/ptj/pzab082

Putri, A. (2018). Pentingnya orang dewasa awal menyelesaikan tugas perkembangannya,. SCHOULID, $3(2)$. https://doi.org/https://doi.org/10.23916/08430011

R, R. (2014). Pengaruh musik mozart dalam mengurangi stres pada mahasiswa yang sedang skripsi. Journal of Educational, Health and Community Psychology, 3(2), 71-78.

Ratnawati. (2018). Hubungan antara tingkat kecemasan dengan kemandirian pelaksanaan aktivitas harian pada klien skizofrenia di rumah sakit jiwa daerah surakarta.

S, N., A, R., \& Baverly, G. (2005). Pengantar psikologi abnormal. Erlangga.

Saputra, T. (2010). Bentuk kecemasan dan resiliensi mahasiswa pascasarjana Aceh-Yogyakarta dalam menghadapi pandemi Covid-19. Jurnal Bimbingan Dan Konseling Ar-Rahman, 6(1). http://dx.doi.org/10.31602/jbkr.v6i1.2941.

Sholeh, M. (2016).Terapi shalat tahajud, Jakarta Naura Books

Sugiyono. (2015). Metode Penelitian kombinasi. Alfabeta.

Tirmidzi. (2018). Bimbingan konseling Islami. Perdana Publishing. 